International Journal of Agriculture, Environment and Bioresearch

Vol. 5, No. 01; 2020

ISSN: $2456-8643$

\title{
POPULAR PERCEPTIONS AND SAND DREDGING AT DEKOUNGBE IN THE BOROUGH OF GODOMEY (BENIN, WEST AFRICA)
}

\author{
HEDIBLE Sidonie Clarisse \\ Inter-Faculty Center for Training and Research in Environment for Sustainable Development \\ (CIFRED \\ Pierre PAGNEY Laboratory: Climate, Water, Ecosystem and Development (LACEEDE), \\ 03BP 1122 Cotonou 03. \\ Department of Sociology-Anthropology \\ Master / Prospective Development Study (Master / EPDev)
}

https://doi.org/10.35410/IJAEB.2020.5472

\begin{abstract}
Population growth is pushing people to use sands for any useful purpose. To meet this demand and at the same time preserve the coastal zones in the face of the danger of erosion, the Beninese State has opted for the exploitation of continental sand, precisely in the marshy and lagoon zones. middle and on living things. The main objective of this research is to analyze the socioenvironmental perceptions and impacts of sand dredging at Dèkoungbé in the commune of Abomey-Calavi. Research of a qualitative and quantitative nature, the reasoned sampling technique was chosen. A total of twenty-eight (28) actors were interviewed. Data collection techniques are observation, interview and administration of the questionnaire with the observation tools, interview guide and questionnaire as appropriate tools.

The results reveal that according to popular perceptions, dredging activities pose a threat to their living environment. These activities also have socio-environmental impacts on the population of Dèkoungbé.
\end{abstract}

Keywords: Popular perceptions, exploitation of sand, dredging of lagoon sand, Dèkoungbé, arrondissement of Godomey.

\section{INTRODUCTION}

Spatial planning and nature protection are challenges for sustainable development. Thus, better management of nature must be based on the maintenance, conservation, development and use of natural resources. However, demographic pressure combined with the ever-increasing strong demand for natural resources is straining the carrying capacity of the environment to meet the survival needs of populations (Ogan, 2012). However, natural resources often exist in limited quantities and constitute wealth in the latent state of the populations which hold them. Unfortunately, their uncontrolled exploitation generates constraints.

Most of the coastal cities of Benin are experiencing a serious degradation of their environment given their geographic location. The coastal areas represent a fragile ecosystem, subject to a 
Vol. 5, No. 01; 2020

ISSN: $2456-8643$

localized phenomenon of coastal erosion. The processes behind this degradation are both natural and anthropogenic (Bessan, 2008). Similarly, in the coastal zone of Benin, the accumulations of sands of the current cordon are abundantly researched and exploited for various uses. This exploitation accelerates coastal erosion and poses serious threats to the environment and to infrastructure on the coast (Adam, 2007).

The desire to provide populations with a healthy environment and the awareness that the proper use of natural resources must tend towards a balance between human needs and the possibilities of nature to meet them, have motivated government authorities to sea sand quarries closed in favor of those in the lagoon sands (Djakou, 1996).

The exploitation of lagoon sand therefore constitutes today a new activity which occupies several actors around the Dèkoungbé swamp. The extraction of lagoon sand is therefore part of a logic of exploitation of continental sand deposits in substitution for marine sand to reduce the pressure on the Beninese coast which is facing environmental problems. Indeed, the strong demographic pressure on the banks constitutes an environmental threat which deserves special attention. It is in this context that the choice of this theme, "Popular perceptions and dredging of lagoon sand at Dèkoungbé in the district of Godomey", fits. These different findings raise several questions, in particular: what perceptions do people have of exploitation of lagoon sand at Dèkoungbé? What are the impacts of the exploitation of lagoon sand on the biophysical and biological environment?

\section{PROBLEM}

The interest of managing the environment in general and natural resources in particular has raised questions for several decades from several authors. Vanpeene-Bruhier et al. (2003) in their work entitled "Environmental risk assessment for sustainable management of space", showed that human activities have a direct or indirect influence on ecosystems on the one hand and sometimes directly on man .

Yabi (2015) has shown that the quarrying activity in the commune of Tchaourou has boosted the local economy but leaves the population suffering.

According to Gonou (2010), the exploitation of continental sand in the district of Perma (Atacora) is carried out in an anarchic manner and does not respect any environmental standard. In his work, he first showed that this activity constitutes a proven source of income for the people who indulge in it and that the environment is completely degraded in this part of the country; which presents dangers to the population because they are large pools which are created especially in the rainy season and where human life is exposed.

For Leduc and Raymond (2000), natural environments quickly receded in the face of advances in "civilization" and built environments in turn became an issue of quality of life. Concerns about the environment really started in Benin in the 1980s. This is why the right to a healthy environment is established in the Republic of Benin as a fundamental human right and the constitution of December 11, 1990 stipulates in its article 27 that "Everyone has the right to a healthy, satisfying and sustainable environment and has the duty to defend it. The State ensures 
Vol. 5, No. 01; 2020

ISSN: $2456-8643$

the protection of the environment "(Constitution of Benin, 1990). Still in its ambition to promote the rational management of its resources and to protect its environment, Benin has also acceded, since January 2000, to the Ramsar convention (Amoussou-Adéblé, 2005).

MINEX BENIN SARL (2011), reports on the relationship that exists between the rational use of natural resources by the populations concerned to satisfy their needs and the consequences of these on the environment identified through its "Study report d 'impacts on the environment; case of the sand dredging project in the swamps of DEKOUNGBE HOUEDOME, Municipality of Abomey-Calavi ". Let's assume that the rational exploitation of natural resources should meet needs. However, it cannot be achieved without affecting the environment in which these deposits are identified and the local population and their activities. The conclusions and overlaps of several studies supported by a group of experts, academics, biologists and geological researchers, reveal ecological consequences, and heavy implications of the extraction of sand on the erosion of the sites and the biodiversity fragility.

The purpose of this recerce is therefore to analyze the socio-environmental perceptions and impacts of sand dredging at Dékoungbé in the commune of Abomey-Calavi.

\section{PRESENTATION OF THE STUDY}

Environment Dékoungbé is located in the arrondissement of Godomey, commune of AbomeyCalavi. The area is bounded to the north by the municipality of Zè, to the south by the Atlantic Ocean, to the east by the municipalities of So-Ava and to the west by the municipalities of ToriBossito and Ouidah. North latitude 6027 'and East longitude 2021' Dékoungbé covers an area of 65,000 ha or $650 \mathrm{~km} 2$ (Fig. 1).

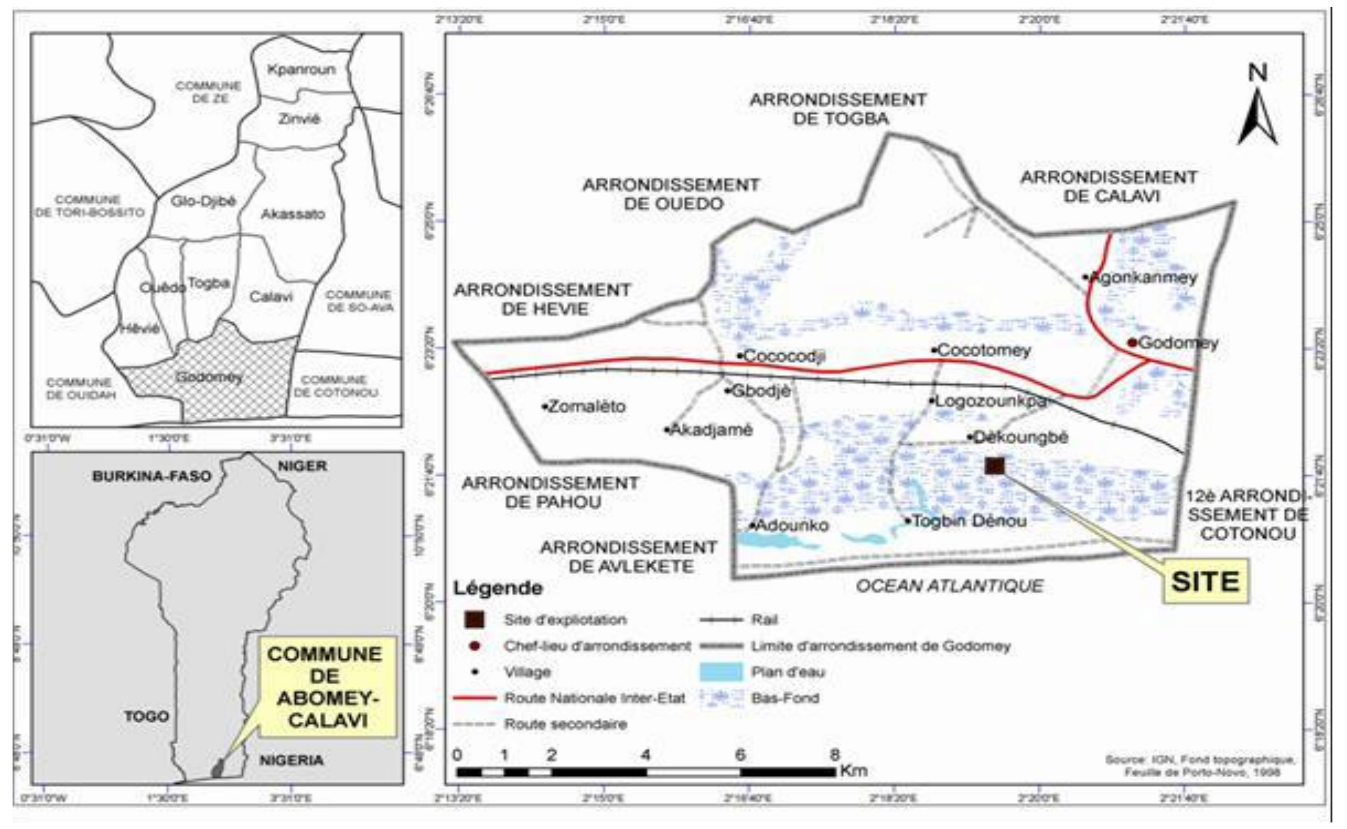

Figure 1: Geographical location of the study area Source: A.I.D.E.S, 2015 The municipality enjoys a hot humid climate of the subequatorial type marked by an alternation of two dry seasons 
with two rainy seasons. Agricultural activities begin with the long rainy season from mid-April to mid-July. Then comes the short dry season which lasts from August until mid-September. It is followed by the small rainy season from mid-October to mid-November. Finally, the long dry season lasts from the beginning of December until March. The average annual rainfall is around $1,200 \mathrm{~mm}$, of which 700 to $800 \mathrm{~mm}$ for the first rainy season and 400 to $500 \mathrm{~mm}$ for the second rainy season. There is a decrease in precipitation from North to South and from East to West. The flora of Dékoungbé is varied according to the facies crossed. Thus one meets mangroves and coconut groves in the coastal area, a degraded savannah on the plateau with a dominance of fallow with oil palm, and a grouping of grasses in the swamps and along the banks of Lake Nokoué. However, the field studies carried out by the design office on the characteristics of ecosystems in the environment suggest the presence of the main species which are: Tyhpaaustralis, Paspalumvaginatum, Eicchhorniacrassipes It is made up of fauna: aquatic, semiaquatic and avian. The middle avian fauna is composed of ichthyophagous birds, they belong to the genera Phalacororax, Ardeola, Egretta, Ceryle etc. The mammals encountered are: Sheep, sheep, dogs, pigs, cows, etc. (A.I.D.E.S; 2015) According to the 4th General Census of Population and Housing (RGPH4).

The total population of the Arrondissement of Godomey is 253,262 inhabitants (including 123,833 men and 129,429 women). In this environment, it is mainly the Xwla of the former chiefdom of Djakin joined by immigrants of Ghanaian origin and Fon elements who have settled on either side of the coastal lagoon. Its organization is based on patrilineal principles and everyone knows their rights and duties as prescribed by tradition. We note the presence of nonnatives such as Fon, Mina, Goun, Péda, Xwla etc. (A.I.D.E.S, 2015). Agriculture, animal husbandry and fishing are the main activities of the populations of the Municipality of AbomeyCalavi. These activities occupy $78.43 \%$ of household heads while the proportion at the national level is $83.35 \%$. The activities of the tertiary sector, namely trade, transport and other services absorb the rest of the active population. (A.I.D.E.S, 2015). Agriculture alone occupies $78 \%$ of households in the Municipality of Abomey-Calavi. The number of working hours is estimated at 5.6 hours on average per day over the whole year. The most dominant crops are corn and cassava, which are the staple food. The presence of swamps favors the cultivation of rice, the proportion of which is limited to small areas on an experimental basis. We observe a cohabitation of natural palm groves and those selected. Agriculture is modernizing more and more with the presence in the sector of traders, retired civil servants and unemployed graduates. These grow vegetables to meet the needs of urban centers for tomatoes and leafy vegetables. They also produce pineapples and citrus fruits on private farms. In the Municipality of Calavi, farming is very underdeveloped. Fishing is practiced by $40 \%$ of the active population of the locality. It comes in many forms. Fishing is an important economic activity in the Municipality of Abomey-Calavi because of the existence of many bodies of water in the area. Over $80 \%$ of Benin's total fishery production comes from the Atlantic Department. During the flood, the floodplain presents extremely interesting ecological characteristics and very useful for fish: spawning habitats, overabundance of food for adults, juveniles and larvae. The destruction of part of this flood zone will lead to a decrease in recruitment in the fluvio-lagoon system. (A.I.D.E.S, 2015)

\section{METHODOLOGICAL APPROACH}


The methodological approach used within the framework of this research takes into account the nature of the research, the documentary research, the sampling technique, the field surveys, the data processing and the analysis of the results. Documentary research consisted in the systematic collection of general works, specific works, articles, reviews and basic maps. To this end, documentation centers have been visited. This documentary phase made it possible to identify and consult certain studies which tackled different aspects of the subject and then helped to develop a much more specific work plan. Table I summarizes the different centers visited and the data collected. Table I: Summaries of documentation centers

\begin{tabular}{|l|l|l|}
\hline Documentation center & Nature of documentation & Types d'information \\
\hline $\begin{array}{l}\text { FASHS documentation } \\
\text { centers }\end{array}$ & $\begin{array}{l}\text { Books, reports, theses, } \\
\text { dissertations and articles }\end{array}$ & $\begin{array}{l}\text { General information of a } \\
\text { methodological nature and } \\
\text { impacts of exploitation of } \\
\text { marine and lagoon sand } \\
\text { Library }\end{array}$ \\
\hline University Library & $\begin{array}{l}\text { Books, theses, dissertations, } \\
\text { reports and articles }\end{array}$ & $\begin{array}{l}\text { General methodological } \\
\text { information }\end{array}$ \\
\hline $\begin{array}{l}\text { MEHU } \\
\text { Center }\end{array}$ & $\begin{array}{l}\text { Documentation articles, reports and } \\
\text { journals }\end{array}$ & $\begin{array}{l}\text { General information on the } \\
\text { subject }\end{array}$ \\
\hline
\end{tabular}

Sampling was carried out by reasoned choice. The target groups involved in sand dredging and the population of Dèkoungbé were interviewed. These are: operators; farmers; sand carriers; dredging quarry officers; populations close to quarries; local authorities and resource persons. Table II presents the number of respondents by target group. 
Table II: Number of respondents per target group

\begin{tabular}{|l|l|}
\hline Target group & $\begin{array}{l}\text { Number } \\
\text { respondents }\end{array}$ \\
\hline operators & 05 \\
\hline fishermen & 04 \\
\hline Sand carriers & 05 \\
\hline Populations close to quarries & 11 \\
\hline Local authorities & 01 \\
\hline Contacts & 02 \\
\hline Total & $\mathbf{2 8}$ \\
\hline
\end{tabular}

Source: Research results, December 2017.

A total of 28 people were interviewed. Several tools and techniques made it possible to collect information in the field.

In order to collect the necessary information on the chosen theme, interviews are conducted with the local authority (district chief) and resource persons on aspects of the activity of exploiting sand in the environment. The questionnaires are sent to the populations to find out their perception with regard to this activity. Observations were made at the dredging site.

The tools used to collect data and information are the questionnaire, the observation grid, the interview guide.

As equipment, the camera for taking the pictures used in the work The survey sheets were counted manually. As for the raw information collected in the field, it is processed by statistical methods of processing survey data using Excel software; Word software for texts and Arc View3.2 for maps. The results of the analysis made it possible to highlight popular perceptions related to dredging and then to have a close-up view of all the environmental problems that arise in general in order to propose certain approaches to solutions likely to contribute to improving the environment.

The quantitative data were processed with Excel software in the form of a table, to facilitate the appreciation of the various impacts generated by the dredging of sand in the Dékoungbé district.

\section{RESULTS AND DISCUSSION}


Vol. 5, No. 01; 2020

ISSN: $2456-8643$

The impact represents the effect on the environment resulting from a level of pollution (air, water or soil) exceeding the permissible level. The direct or indirect effects must be assessed in their short, medium and long term consequences. They can also be positive effects generated in the longer term by men's activities or projects. In reality, they are long-term effects of an activity. For the purpose of this work, it is about the impacts of sand dredging.

The extraction of marshy sand at Dèkoungbé for a purely commercial purpose, is done using large equipment, ELLIOT 670 dredgers, generator sets, CATERPILAR $140 \mathrm{H}$ excavators, CATERPILLAR bulldozers (D6M 4JN01193 and D7G II) and Caterpillar 950 G loaders. As infrastructure, the company has an equipment storage and sand storage area, offices and hangars equipped with sanitary facilities. (A.I.D.E.S; 2015)

\subsection{Impacts of the exploitation of lagoon sand}

Components affected by the exploitation of lagoon sand at Dèkoungbé With the matrix approach, the affected components have been identified. Thus, the sources of impacts linked to the exploitation of lagoon sand, also called sub-activities, were highlighted from Bessan's checklist (2008). These sources of impact are as follows: dredging, transport by boat, land transport, sand storage, truck handling, marketing.

Bessan's matrix (2008) made it possible to compare the sources of impact and the components of the environment elicited. This crossing highlights the components of the environment that are more or less affected, as shown in Table III.

Table III: Matrix for determining the components of the environment affected by the sand mining activity.

\begin{tabular}{|c|c|c|c|c|c|c|c|c|c|}
\hline $\begin{array}{l}\text { Sources } \\
\text { and'impact }\end{array}$ & Air & $\begin{array}{l}\text { Water } \\
\text { (Lagoon } \\
\text { ) }\end{array}$ & Sol & $\begin{array}{l}\text { Flor } \\
\text { a }\end{array}$ & $\begin{array}{l}\text { wildli } \\
\text { fe }\end{array}$ & $\begin{array}{l}\text { Heal } \\
\text { th }\end{array}$ & $\begin{array}{l}\text { Econom } \\
\mathbf{y} \\
\text { local }\end{array}$ & $\begin{array}{l}\text { Navigabilit } \\
\mathbf{y}\end{array}$ & $\begin{array}{l}\text { Agricultu } \\
\text { re }\end{array}$ \\
\hline $\begin{array}{l}\text { Manual } \\
\text { Dredging }\end{array}$ & & $-\quad 1+$ & & - & - & - & & + & \\
\hline $\begin{array}{l}\text { Land } \\
\text { transportation }\end{array}$ & - & - & - & - & - & - & + & - & - \\
\hline Sand storage & - & - & & - & - & - & & & - \\
\hline $\begin{array}{l}\text { Handling and / } \\
\text { or loading }\end{array}$ & - & - & - & - & - & - & + & & - \\
\hline Marketing & & & & & & + & + & + & \\
\hline
\end{tabular}

Source: Bessan (2008) and field survey (December 2014) 
Legend: plus $(+)=$ positive impacts; minus $(-)=$ negative impacts

Analysis of this matrix shows that the components of the human environment outside of health are the least affected. On the other hand, the elements of the natural environment (air, water, soil, flora, and fauna) are the most currently affected by the exploitation of Dèkoungbé lagoon sand.

\subsection{Environmental and socio-economic impacts of the exploitation of lagoon sand}

Impacts on the physical environment

One of the positive impacts of the exploitation of lagoon sand is the desensitization of the lagoon. This incidence increases the depth and extent of the body of water. This facilitates navigation, transport of goods and people, tourism, etc.

Likewise, the exploitation of lagoon sand has the merit of limiting the pressure on sea sand and consequently the reduction of coastal erosion.

Despite these positive impacts, Dèkoungbé is exposed to many negative consequences due to this activity of exploiting lagoon sand. These negative impacts include:

- Degradation of air quality by dust, truck exhaust, unpleasant odors from waste on sites, noise pollution, etc :;

- pollution of water by solid, liquid waste and by engine oils spilled on sand exploitation sites and often drained by runoff and rainwater towards the lagoon;

- Destruction of the lagoon banks which results in the loss of plant and animal biodiversity;

- Destruction of the habitats of aquatic fauna and aquatic flora due to dredging, which leads to disturbance of the ecosystems and the bottom of the lagoon;

- The deterioration of carriageways which give access to sand storage sites by trucks, making the tracks impassable in the rainy season.

Apart from these harmful impacts linked to the extraction of lagoon sand, there is also the ecological risk which threatens the impermeable layer at the bottom of the lagoon. This risk would result in a large-scale ecological disaster if it happened. However, the practice of this activity linked to the exploitation of lagoon sand gives a certain number of benefits to the operators.

\section{Impacts on human beings}

Man, the first factor of development, is at the heart of any transformation process and the creation of wealth. Due to its interdependence with the biophysical elements of the environment, it undergoes, directly or indirectly, the effects resulting from modifications of the natural environments of which it is often the author. 
The exploitation of sand by dredging as planned within the framework of this project uses semiindustrial equipment of short range but for long-term use. Indeed, the main source of risk activities remain and remain the extraction of sand at depth using the dredge and the transport of extracted materials by trucks.

Apart from the risks linked to the handling of machines and dredging on the quarry, the transport of the sand extracted by trucks represents a real threat for the local populations. Added to this are the collateral risks associated with drowning, the collapse of the banks of created water bodies and probably the destruction of precarious housing. The population deplores the installation of sand dredging industries within their habitat accusing them of polluting the environment and disturbing the peace of mind of the populations. The expansion of the exploitation of continental sand, which turns out to be a solution to protect the Beninese coasts has become a nightmare for the population. Here are the words of the interviewees at Dékoungbé: the sand mining site in our locality. Those who operate the site gradually started by closing the rainwater circulation corridors and finally we got to the point where this rainwater can no longer circulate normally. "

In addition, the exploitation of lagoon sand negatively influences the socioeconomic life of the actors. Indeed, the populations living near the exploitation sites are affected by several diseases due to this activity. Thus, respiratory diseases such as asthma and bronchitis (37\% of those surveyed revealed it), sight diseases such as conjunctivitis and blindness of the eyes (28\%), mainly linked to sand dust, smoke released by heavy machinery (trucks) are frequently recorded by stakeholders as ailments and confirmed by the municipality's health workers. The rest of the respondents, 35\%, did not disclose anything that affected them in the exercise of their activities. Faced with the environmental impacts of the exploitation of lagoon sand in the Dèkoungbé swamps, a certain number of measures are being taken to rationalize management and limit risks.

\subsection{Perceptions of the Dèkoungbé populations on sand dredging activities}

The populations deplore the impact of the activity on public facilities such as electric poles belonging to the Beninese Electricity Company (photos 1 and 2) The vibrations emitted by vehicles during the transport of sand disturb the peace of mind of the populations. 


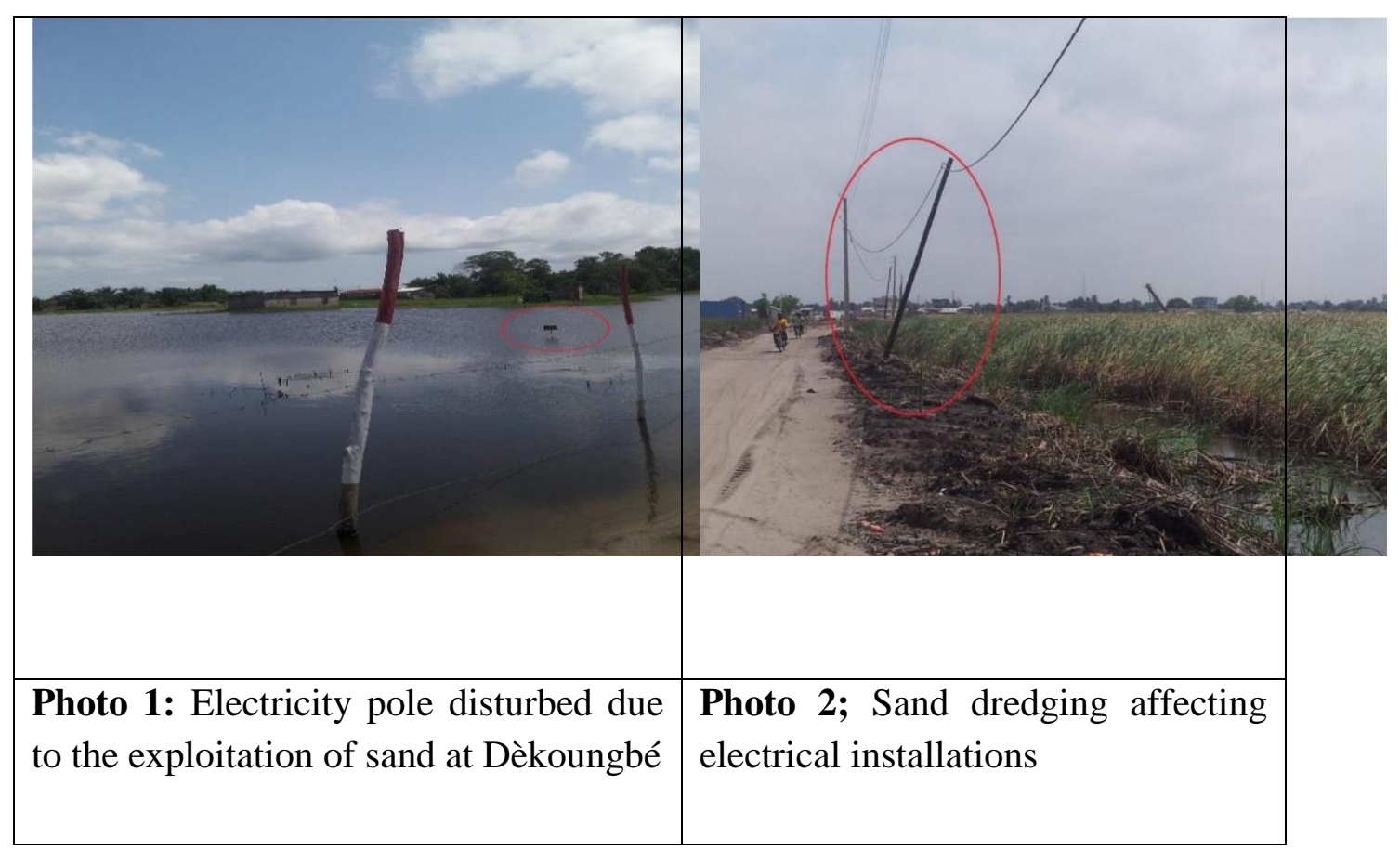

According to popular perception, many are victims of a flood development during rainy periods. Drowned dwellings, shops, workshops, and closed places of worship. Men forced to bend the pants above the knees and women forced to raise the loincloths above the knees. A phenomenon they define as "ordeal" while accusing the promoters of dredging sand operating in the locality.

Residents complain of dust from vehicles transporting sand and the risk of lung infections it can cause in the long term.

They are concerned about the exploitation of the sand which degrades the soil of their locality; then revolted against the drivers responsible for transporting the sand who had already caused several victims of traffic accidents during the transit.

\section{DISCUSSION}

Like African cities, Benin's cities, especially the coastal ones, are subject to strong human pressure. Indeed, the Beninese coast is very fragile due to a very marked demographic pressure of human activities characterized by various developments carried out back to back in recent decades. Dossa (2011) made similar observations in his study on the environmental and socioeconomic impacts of the exploitation of lagoon sand in the arrondissement of Aholouyemè (Municipality of Sèmè-Kpodji). Indeed, its results showed a fragility of the maritime coast linked on the one hand to increasing demographic pressure and on the other hand to the exploitation of sea sand as an income-generating activity for the local populations and actors in the sand sector.

Donou (2007) also came up with similar results, stating that the exploitation of lake sand has impacts on the health of populations. In fact, as part of his work, the author has shown the role of 
Vol. 5, No. 01; 2020

ISSN: 2456-8643

the operating system of a sand deposit on dry land, an environment other than a hydrographic complex. This research had the merit of leading to a better characteristic of the physical and chemical properties of silica sand, its socioeconomic role in Houéyogbé and its industrial importance. He did not fail to reveal that anyone who exploits silica sand runs the risk of respiratory and pulmonary affections among which is silicosis whose pathologies are irreversible and incurable by modern and traditional medicines. The same observations are made by Gnonlonfin (1996) and Vèdogbèton and Olodo (1996), who highlight a concern around the exploitation of continental sands. For local residents, dredging of water bodies could cause the banks to collapse and the banks to recede, which would cause them to lose part of their domain.

Beyond the negative aspects which are noted in the exploitation of lagoon sand and which are essentially linked to the degradation of the environment, the operators derive important socioeconomic interests. Indeed, the exploitation of lagoon sand at Dèkoungbé is favored by several socio-economic factors. The socioeconomic activities practiced by the people living near Dèkoungbé are fishing, market gardening, coconut oil production, trade, exploitation of sand, fish farming, etc.

Compliance with the measures taken by the promoters of the dredging sites in the Environmental and social management plan makes it possible to mitigate the negative impacts of the dredging of lagoon sand in the district of Godomey

\section{REFERENCES}

- Beninese Environment Agency (ABE), 2001. General guide for carrying out an environmental impact study. MEHU, Cotonou, Benin, 77 p. ADAM (K. S.), 2007. National Report on the Marine and Coastal Environment of Benin. MEPN / DGE / CEDA, 68 p.

- AFFAGNON (W. M.) and HONFOGA (T. T. R.), 2005. The exploitation of lagoon sand in the city of Porto-Novo: socio-economic and environmental impacts. Master thesis in geography, UAC / FLASH / DGAT. 108 p.

- AMOUSSOU (E.), 2010. Rainfall variability and hydro sedimentary dynamics of the catchment area of the fluvio-lagoon complex Mono-Ahémé-Couffo (West Africa). Thesis presented for obtaining a doctorate in applied physical geography.

- University of Burgundy, Paris; 313 p.

- BESSAN (V. M.), 2008. Environmental and socio-economic impacts of the exploitation of fluvial sand in the Ouémé valley: case of the municipality of Adjohoun. Master thesis in geography, UAC / FLASH / DGAT, 100 p.

- Maman-Sani ISSA, in-depth Environmental and Social Impact Report of the lagoon sand exploitation project at Dékoungbé-Hedomey in the commune of Abomey-Calavi 2010;

- DJOSSOU (R.), 2014. Vulnerability and adaptation of the populations of the municipality of GrandPopo to floods. Master thesis in regional integration and development. UAC / FLASH / DGAT. 78 p. 
- Didier Pascal DOGUE, Wetlands in Benin: Wealth under the threat of urbanization; Thursday, February 19, 2015;

- A.I.D.E.S, in-depth Environmental and Social Impact Report of the marshy sand exploitation project at Dékoungbé-TogbinDenouGodomey in the commune of Abomey-Calavi Société MINEX BENIN SARL August 2015;

- Beninese Office of Geological and Mining Research (OBRGM), 2000. Mining potentials of Benin. Cotonou, Ministry of Mines, Energy and Hydraulics (MMEH), 52 p.

- A.I.D.E.S, in-depth Environmental and Social Impact Report for the marshy sand exploitation project at Dékoungbé-TogbinDenouGodomey in the commune of Abomey-Calavi Société IBP 2015;

- 2016 planetoscope-statistics section;

- Samuel YONKEU 13th school of IEPF and SIFEE environmental assessment tools for the development of adaptation plans to climate change Niamey republic of NIGER 2009;

- Written by Educ'ActionThe plight of an abandoned population on June 28, 2016;

- Bruce Edwards Finance and Development December 2015;

- 2014 UNEP report. 